\title{
ANALISIS PEMETAAN KEMATANGAN BERPIKIR BERBASIS NEUROSAINS PADA MAHASISWA KEPERAWATAN
}

\author{
A. Saputri Mulyana ${ }^{1^{*}}$, Fausiyah Annisa² ${ }^{2}$ Faisal $^{3}$ \\ 1. Prodi Ilmu Keperawatan, Universitas Patria Artha, Indonesia \\ 2.Prodi Kebidanan, Universitas Patria Artha, Indonesia \\ 3.Prodi Kesehatan Masyarakat Universitas Patria Artha, Indonesia \\ Patria Artha Journal of Nursing Science \\ 2021. Vol. 5(1), 13 - 20 \\ Issn: 25495674 \\ *E-mail: saputrimulyana89@gmail.com \\ e-issn: 25497545 \\ Reprints and permission: \\ http://ejournal.patria-artha.ac.id/index.php/jns
}

\begin{abstract}
Abstrak
Latar Belakang : Salah satu aspek perkembangan manusia adalah perkembangan kognitif yang berkaitan dengan potensi intelektual terutama kemampuan dalam berpikir dan memecahkan masalah. Olehnya itu, kematangan berpikir sangat diperlukan untuk mengembangkan seluruh kemampuannya dalam memperoleh hal baru tentang pengetahuan. Terutama dalam memecahkan suatu masalah, sehingga dapat tetap menjalankan fungsinya secara tepat dan benar. Diantara cara mengukur perkembangan kematangan berpikir pada anak yaitu melalui neurosains. Universitas Patria Artha telah mengembangkan aplikasi Neurosains Terapan sejak tahun 2017. Tujuan dari studi ini adalah untuk menganalisis kematangan berpikir berbasis neurosains terapan pada mahasiswa keperawatan. Metode Penelitian: Melalui studi observasional bersifat deskriptif, pengumpulan data penelitian ini dilakukan menggunakan Aplikasi Neurosains Terapan, dengan total 25 sampel yang dipilih dengan teknik accidental sampling. Hasil: dari studi ini adalah: sebanyak 17 responden (68\%) memiliki kematangan berpikir yang baik dan 8 responden (32\%) menunjukkan bahwa kematangan berpikir masih kurang. Implikasi penelitian: kematangan berpikir seseorang dipengaruhi oleh kemampuan penguasaan diri, Kemampuan bersosialisasi, kemampuan critical thinking, kemampuan analitis, dan kemandiriannya. Rekomendasi: perlu dilakukan penapisan untuk pemetaan kematangan berpikir pada mahasiswa keperawatan di Indonesia.
\end{abstract}

Kata kunci: kematangan berpikir; keperawatan; mahasiswa; neurosains terapan 


\section{Pendahuluan}

Memahami manusia, berarti memahami makhluk hidup secara utuh yang terus mengalami pertumbuhan dan perkembangan. Proses pertumbuhan berhubungan dengan perubahan secara kuantitatif, yaitu adanya peningkatan ukuran dan struktur. Kecepatannya bervariasi sesuai tahapan usia. Sementara perkembangan dikaitkan dengan perubahan kualitatif, yaitu adanya perubahan mencapai kematangannya (maturation), baik dari aspek fisik maupun psikis (Latifa, 2017). Salah satu implikasi dari perkembangan manusia dapat dilihat dari aspek kognitif, yaitu kemampuan intelektual individu (Aghnaita, 2017). Kemampuan ini dipengaruhi oleh perkembangan sel-sel syaraf pusat di otak (Latifa, 2017). Pertumbuhan otak dan sistem syaraf merupakan sebuah kesatuan yang saling berkolaborasi terhadap kematangan kognitif individu. Seiring dengan perkembangan tersebut, adanya rangsangan/ stimulus dari luar sangat berperan penting dalam proses kematangannya.

Kematangan berpikir merupakan salah satu indikator keberhasilan pendidikan sebagai implikasi adanya kemajuan dan perkembangan peserta didik. Cara mengukur perkembangan kematangan berpikir pada anak dapat menggunakan instrumen seperti Inventori Tingkat Perkembangan (ITP) yang dapat dikembangkan dalam program computer, selanjutnya disebut Analisis Tugas Perkembangan (ATP). Sebuah riset menunjukkan, melalui instrumen ATP, rata-rata sebagian anak di Sekolah Dasar (SD) mendapat nilai 2,821. Tingkatan perkembangan ini berada pada kelompok Sadar Diri, masih di bawah batas rata-rata pada kelompok SD di wilayah Kebumen (Priyatnomo, et al., 2017).

Di Indonesia, Universitas Patria Artha merupakan salah satu universitas yang telah mengembangkan sebuah cara dalam memahami kematangan berpikir pada anak, yaitu melalui neurosains terapan. Hal ini merupakan implikasi dari perkembangan neurosains, yang memerhatikan interaksi antara otak dan pikiran, jiwa dan raga, serta hati dan akal. Otak tanpa pikiran tidak akan bermakna kecuali hanya sebatas sebuah organ. Olehnya itu, neuroanatomi (struktur otak) dan neurofisiologi (fungsi otak) merupakan satu kesatuan yang tingkat kematangannya sama-sama perlu dioptimalkan dengan baik (Priyatnomo, et al., 2017).

Neurosains terapan (NST) telah dikembangkan di Universitas Patria Artha, baik secara aplikatif maupun secara akademis. Setelah merumuskan NST, Universitas Patria Artha juga telah mengembangkan aplikasi NST yang telah di HAKI-kan oleh Kementerian Hukum dan HAM sejak tanggal 8 Agustus 2017 di Makassar. Selain itu, neurosains terapan telah diimplementasikan pada pemerintahan kota Makassar melalui penerbitan Peraturan Walikota Makassar Nomor 19 Tahun 2019 tentang Peningkatan Kualitas Pendidikan dan Sumber Daya Manusia Berbasis NST.

Sebuah studi kualitatif mengemukakan bahwa proses belajar di kelas merupakan salah satu faktor yang dapat memicu stres pada mahasiswa keperawatan, yang kemudian berefek pada hasil pembelajarannya (Ritonga, 2015). Olehnya itu, mahasiswa perlu memahami potensi pada diri masingmasing, termasuk pada perkembangan kematangan berpikirnya. Sehingga diharapkan dapat mengoptimalkan awareness dan melakukan upaya dalam meningkatkan kematangan berpikirnya sesuai dengan perkembangan usianya Trihadi, et al., 2017).

Studi awal pada tahun 2019 oleh Lembaga Manajemen Universitas Patria Artha pada pegawai pemerintahan di Kota Makassar menunjukkan adanya perbedaan kematangan berpikir yang teridentifikasi melalui aplikasi neurosains terapan Universitas Patria Artha. Tujuan khusus dari penelitian ini adalah diketahuinya kematangan berpikir berbasis neurosains terapan pada mahasiswa Keperawatan Universitas Patria Artha. Adanya perbedaan 
kematangan berpikir pada setiap individu serta masih minimnya studi tentang neurosains di Indonesia terutama dalam dunia pendidikan di bidang keperawatan membuat penulis tertarik untuk mengkaji dan menganalisis kematangan berpikir pada mahasiswa, khususnya pada mahasiswa keperawatan. Diharapkan hasil kajian ini dapat menjadi acuan dalam merumuskan inovasi dalam rangka meningkatkan kemampuan berpikir mahasiswa keperawatan sebagai salah satu aset bangsa.

\section{Metode}

Penelitian ini merupakan studi observasional bersifat deskriptif untuk mengetahui gambaran kematangan berpikir pada mahasiswa keperawatan yang dilakukan dengan pendekatan crosssectional.

Penelitian ini dilakukan di Universitas Patria Artha Makasar, pada bulan April- September 2020, dengan populasi adalah semua mahasiswa Prodi Ilmu Keperawatan Fakultas Kesehatan Universitas Patria Artha. Jumlah sampel pada penelitian ini adalah 25 orang yang dipilih secara accidental sampling.

Adapun pengumpulan data dilakukan melalui penapisan kematangan berpiki responden menggunakan aplikasi Neurosains Terapan (NST) yang telah diHAKI-kan oleh Universitas Patria Artha. Instrumen yang digunakan adalah aplikasi Neurosains Terapan untuk membaca dan menganalisis kematangan berpikir mahasiswa keperawatan.

Analisis data penelitian ini dilakukan berdasarkan mekanisme kerja program Aplikasi NST. Hasil penapisan kematangan berpikir responden kemudian dinarasikan oleh pakar NST. Kemudian hasilnya dipersentasekan menggunakan SPSS.

Pelaksanaan penelitian ini menerapkan prinsip beneficience, autonomy, nonmaleficience, confidentiality, dan justice.
Hasil

\section{Karakteristik Responden}

Berdasarkan hasil pengelohan data yang dilakukan dari 25 responden, maka disajikan data tersebut sebagai berikut:

1) Distribusi frekuensi berdasarkan jenis kelamin responden

Tabel 1

Distribusi Frekuensi Jenis Kelamin Responden

\begin{tabular}{ccc}
\hline Jenis Kelamin & $\mathbf{n}$ & $\%$ \\
\hline Laki-laki & 8 & 32.0 \\
\hline Perempuan & 17 & 68.0 \\
\hline Total & 25 & 100.0
\end{tabular}

Sumber: Data Primer

Berdasarkan tabel 1, jenis kelamin perempuan sebanyak 17 responden (68\%) dan jenis kelamin laki-laki sebanyak 8 responden (32\%).

2) Distrubisi frekuensi berdasarkan usia responden

Tabel 2

Distribusi frekuensi usia responden

\begin{tabular}{ccc}
\hline Usia (tahun) & $\mathbf{n}$ & $\%$ \\
\hline 18 & 1 & 4.0 \\
\hline 19 & 3 & 12.0 \\
\hline 20 & 4 & 16.0 \\
\hline 21 & 5 & 20.0 \\
\hline 22 & 8 & 32.0 \\
\hline 23 & 4 & 16.0 \\
\hline Total & 25 & 100.0
\end{tabular}

Sumber: Data Primer

Berdasarkan tabel 2, kategori usia terendah responden adalah 18 tahun dengan jumlah 1 orang (4\%). Kategori usia tertinggi responden berada pada usia 23 tahun dengan jumlah 4 orang (16\%). Adapun jumlah responden terbanyak terdapat pada kategori usia 22 tahun, yaitu sebanyak 8 orang (32\%).

3) Distribusi frekuensi berdasarkan kematangan berpikir responden 
Tabel 3

Distribusi frekuensi kematangan berpikir responden

\begin{tabular}{ccc}
\hline $\begin{array}{c}\text { Kematangan } \\
\text { Berpikir }\end{array}$ & $\mathbf{n}$ & $\%$ \\
\hline Baik & 17 & 68.0 \\
\hline Kurang & 8 & 32.0 \\
\hline Total & 25 & 100.0 \\
\hline Sumber: Data Primer & & \\
\hline
\end{tabular}

Sumber: Data Primer

Berdasarkan tabel 3, sebagian besar responden menunjukkan kematangan berpikir yang baik dengan jumlah 17 orang $(68 \%)$. Sementara 8 orang lainnya (32\%) menunjukkan bahwa kematangan berpikir kurang.

4) Distribusi frekuensi berdasarkan penguasaan diri responden

Tabel 4

Distribusi frekuensi penguasaan diri responden

\begin{tabular}{ccc}
\hline Penguasaan Diri & $\mathbf{n}$ & $\%$ \\
\hline Baik & 18 & 72.0 \\
\hline Kurang & 7 & 28.0 \\
\hline Total & 25 & 100.0 \\
\hline
\end{tabular}

Sumber: Data Primer

Berdasarkan tabel 4, sebagian besar responden memiliki penguasaan diri yang baik, yakni mencapai 18 orang (72\%), sementara 7 orang sisanya (28\%) memiliki penguasaan diri yang kurang.

5) Distribusi frekuensi berdasarkan kemampuan bersosialisasi responden

Tabel 5

Distribusi frekuensi kemampuan bersosialisasi responden

\begin{tabular}{ccc}
\hline $\begin{array}{c}\text { Kemampuan } \\
\text { Bersosialisasi }\end{array}$ & $\mathbf{n}$ & $\%$ \\
\hline Baik & 18 & 72.0 \\
\hline Kurang & 7 & 28.0 \\
\hline Total & 25 & 100.0 \\
\hline
\end{tabular}

Sumber: Data Primer

Berdasarkan tabel 5, sebagian besar responden memiliki kemampuan bersosialisasi yang baik, yakni mencapai 18 orang $(72 \%)$, sementara 7 orang sisanya Penulis liliskarlina, A. Saputri mulyana
(28\%) kurang memiliki kemampuan bersosialisasi.

6) Distribusi frekuensi berdasarkan critical thinking responden

Tabel 6

Distribusi frekuensi critical thinking responden

\begin{tabular}{ccc}
\hline $\begin{array}{c}\text { Critical } \\
\text { Thinking }\end{array}$ & $\mathbf{n}$ & $\%$ \\
\hline Baik & 12 & 48.0 \\
\hline Kurang Baik & 13 & 52.0 \\
\hline Total & 25 & 100.0 \\
\hline
\end{tabular}

Sumber: Data Primer

Berdasarkan tabel 5, sebagian besar responden memiliki critical thinking yang baik, yakni mencapai 12 orang (48\%), sementara 13 orang lainnya (52\%) memiliki critical thinking yang kurang baik.

7) Distribusi frekuensi berdasarkan kemampuan analitis responden

Tabel 7

Distribusi frekuensi kemampuan analitis responden

\begin{tabular}{ccc}
\hline $\begin{array}{c}\text { Analitis, } \\
\text { Pemecahan } \\
\text { Masalah }\end{array}$ & $\mathrm{n}$ & $\%$ \\
\hline Baik & 11 & 44.0 \\
\hline Kurang & 14 & 56.0 \\
\hline Total & 25 & 100.0 \\
\hline Sumber: Data Primer & &
\end{tabular}

Berdasarkan tabel 7, sebagian besar responden memiliki kemampuan analitis yang kurang, yakni mencapai 14 orang (56\%), sementara 11 orang sisanya (44\%) memiliki kemampuan analitis yang baik.

8) Distribusi frekuensi berdasarkan kemandirian responden (aplikator) Tabel 8

Distribusi frekuensi kemandirian responden

\begin{tabular}{ccc}
\hline Kemandirian & $\mathbf{n}$ & $\%$ \\
\hline Baik & 15 & 60.0 \\
\hline Kurang & 10 & 40.0 \\
\hline Total & 25 & 100.0 \\
\hline
\end{tabular}

Sumber: Data Primer 
Berdasarkan tabel 8, sebagian besar responden memiliki kemandirian yang baik, yakni mencapai 15 orang $(60 \%)$, sementara 10 orang sisanya $(44 \%)$ memiliki kemampuan analitis yang kurang.

\section{Pembahasan}

Hasil penelitian ini menunjukkan tentang menunjukkan kematangan berpikir mahasiswa keperawatan. Dari 25 responden yang dianalisis melalui penapisan menggunakan Aplikasi Neurosains Terapan (NST), maka diperoleh bahwa sebanyak 17 responden (68\%) memiliki kematangan berpikir yang baik. Sedangkan 8 responden lainnya (32\%) menunjukkan bahwa kematangan berpikir masih kurang. Distribusi kematangan berpikir ini secara spesifik ditinjau dari aspek kemampuan terhadap: penguasaan diri; bersosialisasi; critical thinking; kemampuan analitis; dan kemandirian responden.

Kemampuan penguasaan diri dimaknai sebagai kemampuan untuk mengendalikan perilaku. Hasil studi ini menemukan bahwa sebanyak 18 responden (72\%) memiliki penguasaan diri yang baik dan hanya 7 responden $(28 \%)$ memiliki penguasaan diri yang kurang. Dari 18 responden yang memiliki penguasaan diri yang baik itu, terdapat 1 responden belum memiliki kematangan berpikir yang baik. Sedangkan dari 7 responden yang memiliki penguasaan diri yang kurang tersebut, semuanya belum memiliki kematangan berpikir yang baik. Kajian riset ini menunjukkan bahwa 1 responden yang belum memiliki kematangan berpikir yang baik tersebut berkorelasi dengan kurang baiknya kemampuan bersosialisasi, kemampuan critical thinking, analitis, dan kemandiriannya.

Hasil observasi menemukan bahwa responden tersebut memiliki kemampuan akademis yang baik, namun memang terbukti kurang dalam kemampuan bersosialisasi. Terlihat bahwa responden tersebut memiliki kelompok khusus dalam menjalin pergaulan dengan teman sebayanya. Selain itu, juga terbukti dalam pantauan peneliti, bahwa responden tersebut memiliki kemampuan analitis yang kurang, terutama dalam upayaupaya pemecahan masalah di kelompoknya.

Beberapa kajian literatur menguraikan bahwa pencapaian kedewasaan individu ditandai dengan kemampuan dalam mengendalikan diri dengan ketangguhan dan kemampuannya dalam beradaptasi. Kemampuan dalam mengendalikan diri (self control) bahkan dianggap sebagai sebuah keterampilan dari kecerdasan emosional yang dimiliki oleh individu. Kemampuan ini diyakini dapat meningkatkan prestasi belajar seseorang (Hidayat, 2009) dan berpengaruh terhadap kemampuan dalam memahami pelajaran (Sari, 2013). Seseorang yang memiliki kemampuan yang baik untuk mengontrol atau menguasai dirinya, cenderung mampu mengolah diri dalam menentukan perilakunya berdasarkan standar nilai yang berlaku. Seperti kesesuaian sikap dengan nilai, norma, moral, dan aturan-aturan yang berlaku di masyarakat (Marsela \& Supriatna, 2019).

Kemampuan

bersosialisasi merupakan kemampuan untuk dapat beradaptasi/menyesuaikan diri dengan lingkungannya. Kemampuan ini seiring dengan kemampuan seseorang dalam memainkan peran sosialnya sebagai manusia. Studi ini membuktikan bahwa sebagian besar responden memiliki kemampuan bersosialisasi yang baik, yakni mencapai 18 orang (72\%), sementara 7 orang sisanya (28\%) kurang memiliki kemampuan bersosialisasi.

Dari 18 responden yang memiliki kemampuan bersosialisasi yang baik itu, terdapat 2 responden belum memiliki kematangan berpikir yang baik. Hasil kajian riset ini menunjukkan bahwa 1 responden diantaranya berkorelasi dengan kurang baiknya kemampuan bersosialisasi, kemampuan critical thinking, analitis, dan kemandiriannya. Kemudian 1 responden lainnya memiliki kemandirian yang baik, namun kemampuan critical thinking dan analitisnya kurang. Sedangkan dari 7 responden yang memiliki kemampuan 
bersosialisasi yang kurang tersebut, terdapat 1 responden yang memiliki kematangan berpikir yang baik, dengan kemandirian yang baik pula, namun kemampuan critical thinking dan analitisnya kurang. Hasil observasi peneliti menguatkan studi ini bahwa responden tersebut memang terlihat memiliki kemandirian yang baik, namun kemampuan analitis dan ciritical thinkingnya masih kurang dibanding dengan anggota kelompoknya yang lain.

Sementara itu, kemampuan critical thinking adalah kemampuan dalam mengenali masalah dan menemukan alternatif solusi terhadap masalah tersebut. Kemampuan ini berintegrasi dengan kemampuan untuk memahami, menerapkan, mensintesis, dan mengevaluasi informasi yang didapatkan. Berdasarkan penelitian ini, sebagian besar responden memiliki critical thinking yang baik, yakni mencapai 12 orang (48\%), sementara 13 orang lainnya (52\%) memiliki critical thinking yang kurang baik. Hasil studi ini menunjukkan bahwa dari 13 responden tersebut, terdapat 5 responden belum memiliki kematangan berpikir yang baik. Sedangkan 8 orang lainnya, meskipun memiliki kemampuan berpikir yang baik, namun kemampuan critical thinkingnya kurang. Sebagian besar responden tersebut juga diikuti dengan kurangnya kemampuan analitis. Sebuah studi mengemukakan bahwa kemampuan berpikir kritis sangat berperan dalam membentuk perkembangan kognitif, perkembangan social, dan perkembangan moral seseorang (Zubaidah, 2010). Adapun kemampuan analitis dimaknai sebagai sebuah kemampuan berpikir untuk menguraikan, merincikan, dan menganalisis informasi dalam memahami suatu pengetahuan menggunakan akal dan logikanya. Studi ini mengemukakan bahwa sebagian besar responden memiliki kemampuan analitis yang kurang, yakni mencapai 14 orang (56\%), sementara 11 orang sisanya (44\%) memiliki kemampuan analitis yang baik.

Sedangkan kemandirian adalah kemampuan seseorang untuk mengelola potensi diri untuk mencapai suatu tujuan.

Penulis liliskarlina, A. Saputri mulyana
Studi ini menunjukkan bahwa sebagian besar responden memiliki kemandirian yang baik, yakni mencapai 15 orang (60\%), sementara 10 orang sisanya (44\%) memiliki kemampuan analitis yang kurang. Dari ke-10 responden tersebut, 3 orang diantaranya memiliki kematangan berpikir yang baik. Meskipun terlihat bertolak belakang, namun ketiga responden tersebut memang memiliki kemampuan bersosialisai yang baik. Sementara 7 responden lainnya juga memiliki kematangan berpikir yang kurang baik.

Berdasarkan kajian tersebut, maka dapat disimpulkan bahwa kematangan berpikir individu memang sangat erat kaitannya dengan kemampuan penguasaan diri, Kemampuan bersosialisasi, kemampuan critical thinking, kemampuan analitis, dan kemandirian seseorang.

\section{Simpulan}

Sebanyak 17 responden (68\%) memiliki kematangan berpikir yang baik dan 8 responden (32\%) menunjukkan bahwa kematangan berpikir masih kurang. Kematangan berpikir seseorang dipengaruhi oleh kemampuan penguasaan diri, Kemampuan bersosialisasi, kemampuan critical thinking, kemampuan analitis, dan kemandiriannya.

\section{Ucapan Terima Kasih}

Ucapan terimakasih kepada Kementerian Pendidikan dan Kebudayaan atas bantuan materi melalui dana hibah Simlitabmas pada program Penelitian Dosen Pemula, sehingga penelitian ini dapat terlaksana secara maksimal.

\section{Daftar Pustaka}

Aghnaita. Perkembangan fisik-motorik anak 4-5 tahun pada Permendikbud No. 137 tahun 2014 (kajian konsep perkembangan anak). Jurnal Pendidikan Anak, 3 (2). 219-221. 2017.

Hidayat. Pengendalian diri salah satu keterampilan kecerdasan emosional untuk meningkatkan prestasi belajar siswa sejak dini. Madrasah. 2 (1). 
Tersedia

pada:

https://media.neliti.com/media/publica tions/148462-ID-pengendalian-diri-salahsatu-keterampila.pdf. 2009.

Latifa, U. Aspek perkembangan pada anak sekolah dasar: masalah dan perkembangannya. Journal of Multidiciplinary Studies, 2 (1). 186-196. 2017.

Marsela, R., D. \& Supriatna, M. Control diri: definisi dan factor. Journal of Innovayive Counseling: Theory, Practice, \& Research. 3 (2). 65-69. 2019.

Peraturan Walikota Makassar Nomor 19 Tahun 2019 tentang Peningkatan Kualitas Pendidikan dan Sumber Daya Manusia Berbasis Neurosains Terapan.

Priyatnomo, et al. Aspek kematangan berfikir (intelektual) anak SD di wilayah Kebumen. Prosiding Seminar Nasional Inovasi Pendidikan. 538- 544. 2017.

Sari, Y., K. Pengaruh pengendalian diri dan perilaku belajar terhadap tingkat pemahaman pengantar akuntansi: studi empiris pada mahasiswa program studi akuntansi fakultas ekonomi universitas negeri padang) (Skripsi). Universitas Negeri Padang. Tersedia pada: http://ejournal.unp.ac.id/students/inde x.php/akt/article/viewFile/108/96.

2013.

Trihadi, D., et al. Assertiveness Training Can Increase Nursing Student Confidence. Jurnal INJEC. 2 (1). 34-43. 2017.

Zubaidah. Berpikir kritis: kemampuan berpikir tingkat tinggi yang dapat dikembangkan melalui pembelajaran sains. Makalah pada Seminar Nasional Sains 2010 di Pascasarjana Universitas Negeri Surabaya, 16 Januari 2010. Tersedia pada: https://www.researchgate.net/publicati on/318040409_Berpikir_Kritis_Kemampua n_Berpikir_Tingkat_Tinggi_yang_Dapat_Di kembangkan_melalui_Pembelajaran_Sain s/link/59564c650f7e9b591cda994b/downl oad. 2010.

Penulis liliskarlina, A. Saputri mulyana 
Patria ARTHA Journal of Nursing Science. Vol. 5, No.1, April 2021 